Zoologica Poloniae (2009-2010) 54-55/1-4: 5-12

DOI: $10.2478 / \mathrm{v} 10049-010-0001-3$

\title{
SPERM TRANSFER THROUGH THE VECTOR TISSUE IN PISCICOLA RESPIRANS (CLITELLATA, HIRUDINEA, PISCICOLIDAE)
}

\author{
Piotr ŚwiąteK ${ }^{1}$, Anna Świder ${ }^{1}$ and Aleksander Bielecki ${ }^{2}$ \\ ${ }^{1}$ Department of Animal Histology and Embryology, Silesian University, \\ Bankowa 9, 40-007 Katowice, Poland \\ ${ }^{2}$ Department of Zoology, University of Warmia and Mazury, Oczapowskiego 5, \\ 10-967 Olsztyn-Kortowo, Poland \\ Correspondence to: Piotr Świątek, Department of Animal Histology \\ and Embryology, Silesian University, Bankowa 9, 40-007 Katowice, Poland. \\ tel. +48 32 3591361, fax. +48 32 2591318, e-mail: piotr.swiatek@us.edu.pl
}

\begin{abstract}
In fish leeches (Piscicolidae) indirect (hypodermic) insemination has evolved, thus the spermatophores are released in the specialised region of the body wall known as a copulatory area or a copulatory region. The way in which the spermatozoa reach the ovaries is not fully understood. In piscicolids beneath the copulatory area there is a specialized connective tissue (vector tissue), which is thought to guide the spermatozoa toward the ovaries. To date the structure of the vector tissue has not been observed in copulating specimens, which have spermatophores implanted in their coplulatory area. Here we present the first ultrastructural observation of massive sperm transfer from the spermatophore throughout the vector tissue to the ovaries. Our results show that the sperm transfer is both massive and rapid. The migrating spermatozoa form huge aggregations which push aside the vector tissue cells, in such a way that between these cells voluminous gaps are formed. Unexpectedly to our previous suggestions, the ultrastructural pictures show that the long cytoplasmic processes of granular cells, which constitute the main mass of the vector tissue, are not engaged in sperm transport. We suggest that the sperm is pumped with a high pressure from the spermatophore into the vector tissue, and as a result the vector tissue cells are pushed aside and spermatozoa can freely pass between them.
\end{abstract}

Key words: Annelida, Oligochaeta, leeches, spermatophore, spermatozoa, conducting tissue, ultrastructure. 


\section{INTRODUCTION}

In leeches with the indirect (hypodermic) mode of insemination (i.e. acanthobdellids, rhynchobdellids and erpobdellids) the spermatophores may be implanted anywhere in the body and then the spermatozoa must reach the ovary somehow. The way of sperm migration through the body wall and internal spaces or organs towards the ovaries is poorly known (MANN, 1961; ŚWIĄTEK et al., 2007). Acanthobdellids and most piscicolid leeches have a specialized body region near the gonopores, i.e. copulatory area (copulatory region) where the spermatophores are usually implanted (BRUMPt, 1900; HaRANT and Grassé, 1959; Mann 1961; SAWyer, 1986; Fernández et al., 1992; ŚWiątek et al., 2007). In most piscicolid leeches just beneath the copulatory area a specialized form of connective tissue i.e. vector tissue (conducting tissue) occurs. It was demonstrated that this tissue is engaged in sperm transfer from copulatory area towards ovaries (BRUMPT, 1900; Ś WIĄTEK et al., 2007). Recently, the organization of vector tissue has been studied at the electron microscopy level (ŚWIatek et al., 2007). ŚWIAtek et al. (2007) described the ultrastructure of vector tissue before and after sperm transfer and suggested the active role of vector tissue cells in sperm transmission, however, the exact moment of sperm transfer through the tissue has not been observed. In the present paper the ultrastructure of the vector tissue in copulating specimens of Piscicola respirans (Piscicolidae) is presented. In copulating specimens the spermatophore is attached to the copulatory area, thus the transfer of spermatozoa via vector tissue towards ovaries can be studied. The obtained results allow to verify the previous suggestions about the role of vector tissue in sperm transfer in piscicolid leeches.

\section{MATERIAL AND METHODS}

In the present study the copulating specimens of Piscicola respirans (Troschel, 1850) were used. The specimens were collected from Leuciscus cephalus L. 1758 from San River in southern Poland in 2007.

\section{Light and transmission electron microscopy}

The specimens were dissected and body fragments with copulatory area were fixed in $2.5 \%$ glutaraldehyde in $0.1 \mathrm{M}$. phosphate buffer $(\mathrm{pH}=7.4)$ at room temperature for several days. After washing in phosphate buffer, the material was postfixed for $1 \mathrm{~h}$ in $1 \% \mathrm{OsO}_{4}$ in the same buffer, then dehydratated in a graded series of ethanol and acetone and afterwards embedded in Epon 812 (Fullam Inc., Latham, NY, USA). Semithin sections $(0.7 \mu \mathrm{m}$ thick) were stained with methylene blue and examined with an Olympus BX60 microscope. Ultra-thin sections $(70-80 \mathrm{~nm})$ were cut on a Leica ultracut UCT ultramicrotome. After contrasting with uranyl acetate and lead citrate, the sections were examined in a Hitachi $\mathrm{H} 500$ electron microscope at $75 \mathrm{kV}$. 


\section{RESULTS}

\section{Vector tissue structure}

The organization of the vector tissue in Piscicola respirans is very similar to that previously described in other piscicolid leeches, with one exception only (see below) (Świątek et al., 2007). Briefly, the vector tissue lies just beneath the copulatory area, so that the implanted spermatophore is in immediate contact with it, and the spermatozoa flow from the spermatophore directly towards the vector tissue (Figs. 1-4). In P. respirans vector tissue is composed of several cell types and an extracellular matrix. The outermost part of the tissue is formed by vesicular and flat envelope cells (Fig. 5). Both kinds of cells are embedded in extracellular matrix and covered by basal lamina (Fig. 5, 8; for more detailed description see ŚWIĄTeK et al., 2007). The main mass of the tissue is formed by the granular cells (Figs. 5-9). The cytoplasm of these cells contains characteristic electron-dense granules (Figs. 5-8). Additionally, the cortical cytoplasm of granular cells is broad, devoid of cell organelles and forms long and convoluted projections (Fig. 5-7, 9). In contrast to the previous study (Ś WIĄTEK et al., 2007) the so-called plasmatic cells have never been observed in vector tissue of $P$. respirans. Single muscle strands run across the vector tissue in different directions (Figs. 1, 7).

\section{Transfer of spermatozoa through the vector tissue}

The sperm transfer seems to be very rapid. At the same time, when the sperm is still inside the spermatophore (Fig. 1), other spermatozoa can be observed flowing through the vector tissue (Figs. 2, 3) and a mass of sperm fills the ovary (Fig. 4). The spermatozoa migrating via the vector tissue form huge aggregations which seem to push aside the vector tissue cells in such a way that voluminous gaps are formed between them (Figs. 2, 3, 6, 7). The shape of granular cells does not change during sperm transfer. These cells adhere tightly to each other (except the places where they are separated by the spermatozoa stream - Figs. 6, 7) and their cytoplasmic processes do not form any folds facing intercellular spaces (Figs. 6, 7,9). It is worth noting here that the spermatozoa were never found outside the vector tissue and ovaries.

\section{DISCUSSION}

Since first description of the vector tissue it has been suggested that this tissue plays a main role in sperm transfer (BRUMPT, 1900). Recently ŚWiąteK et al. (2007) have studied four species of the genus Piscicola and demonstrated that indeed spermatozoa migrate through the vector tissue towards the ovaries. According to these authors, the outermost part of the vector tissue, i.e. the vesicular and flat envelope cells, is embedded in an extracellular matrix and lined by basal lamina which protects the spermatozoa from leaking from the tissue, whereas the main mass of the tissue (i.e. granular and plasmatic cells) changes its shape during sperm transfer allowing fast transmission of spermatozoa from 

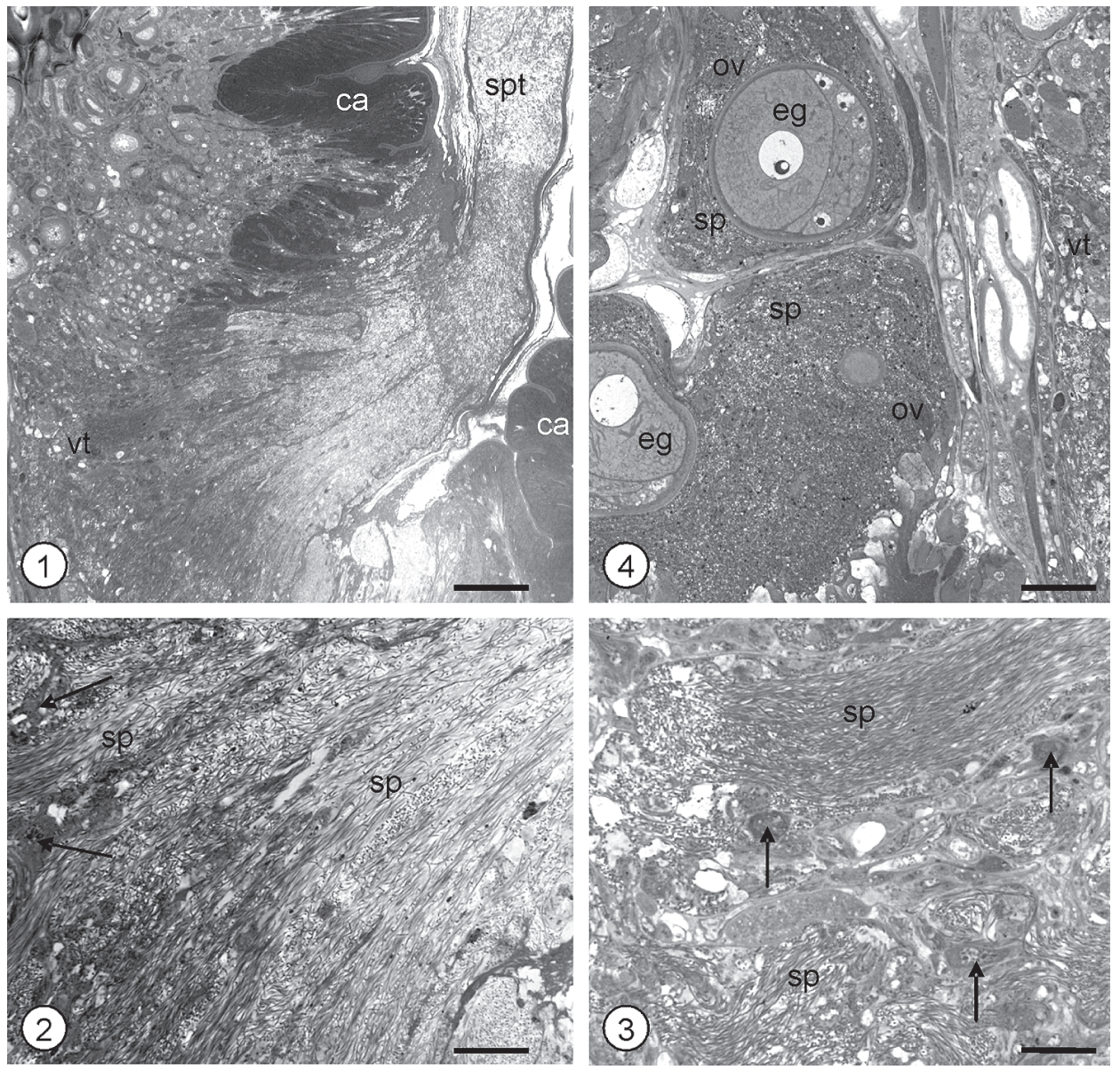

Figs. 1-4. Spermatozoa migration through the vector tissue in Piscicola respirans. Fig. 1. The spermatophore (spt) is implanted into a specialized part of leech body known as copulatory area (ca). Below the copulatory area the vector tissue (vt) is visible. Light microscopy (LM), methylene blue staining, bar $=60 \mu \mathrm{m}$.

Figs. 2, 3. Spermatozoa ( $\mathrm{sp}$ ) migrate via the vector tissue in huge accumulations, pushing aside the vector tissue cells (arrows). LM, methylene blue staining, bars $=15 \mu \mathrm{m}$ in Fig. 2 and $10 \mu \mathrm{m}$ in Fig. 3 .

Fig. 4. Fragments of the ovary (ov) of the same specimen as in Figs. 1-3. While the sperm is still in the spermatophore (Fig. 1) and migrates through the vector tissue (Figs. 1, 2) the ovaries are already filled with sperm mass (sp). Eg, developing egg follicles, vt, vector tissue. LM, methylene blue staining, bar $=35 \mu \mathrm{m}$. 
Figs. 5-7. Vector tissue ultrastructure during sperm transfer.

Fig. 5. The outermost part of the vector tissue. Fragments of vesicular cells (vc) and thin layer of extracellular matrix (thin arrows) are visible. A thin strand of vector tissue composed of granular cells (gc) is also visible Thick arrows indicate the cortical cytoplasm of granular cells forming long projections. Transmission electron microscopy (TEM), bar $=2 \mu \mathrm{m}$.

Figs. 6-7. Migrating spermatozoa (sp) push granular cells $(\mathrm{gc})$ aside. Note that the processes of granular cells (arrows) do not from any free spaces. Mc, profiles of muscle cells. TEM, bars $=2.2 \mu \mathrm{m}$.
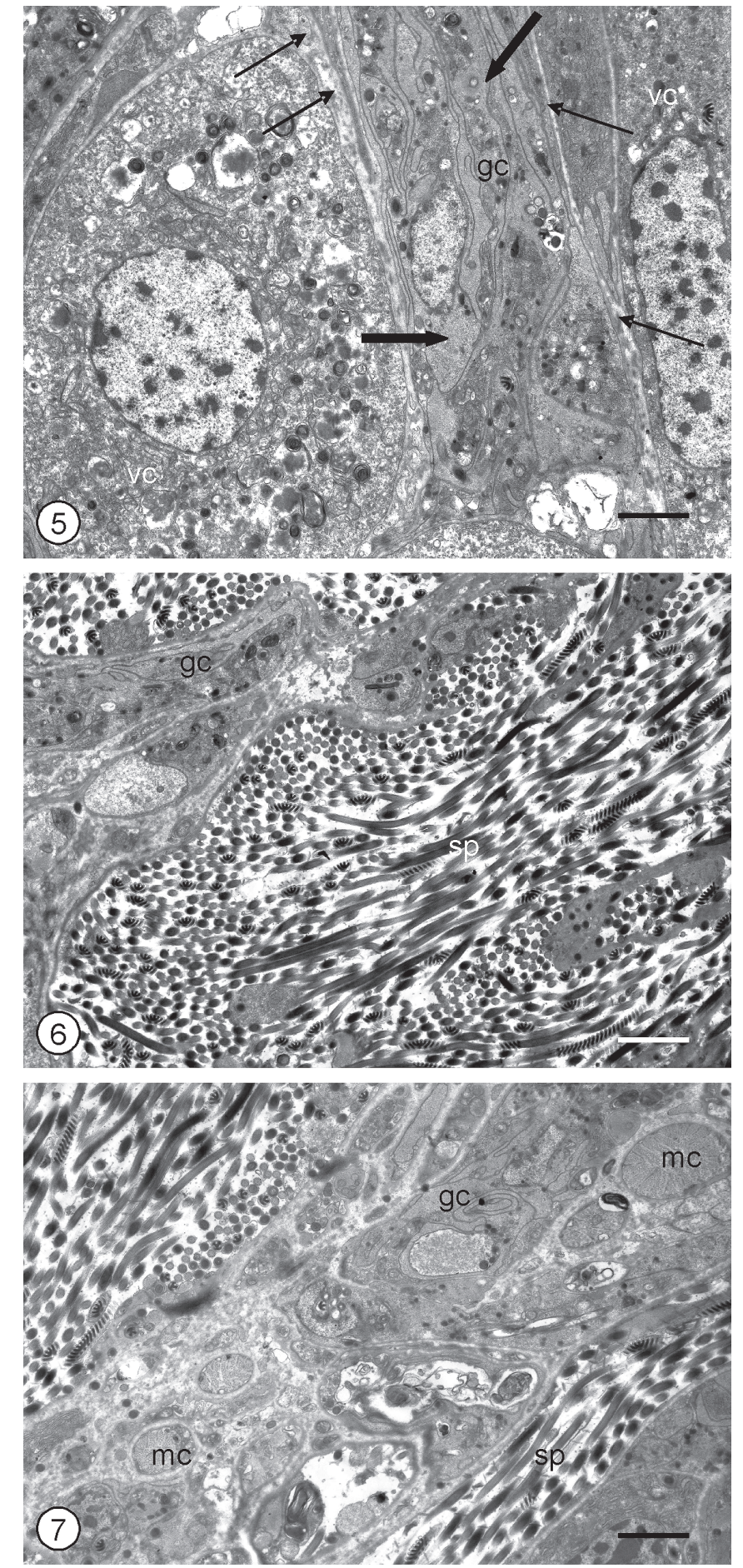


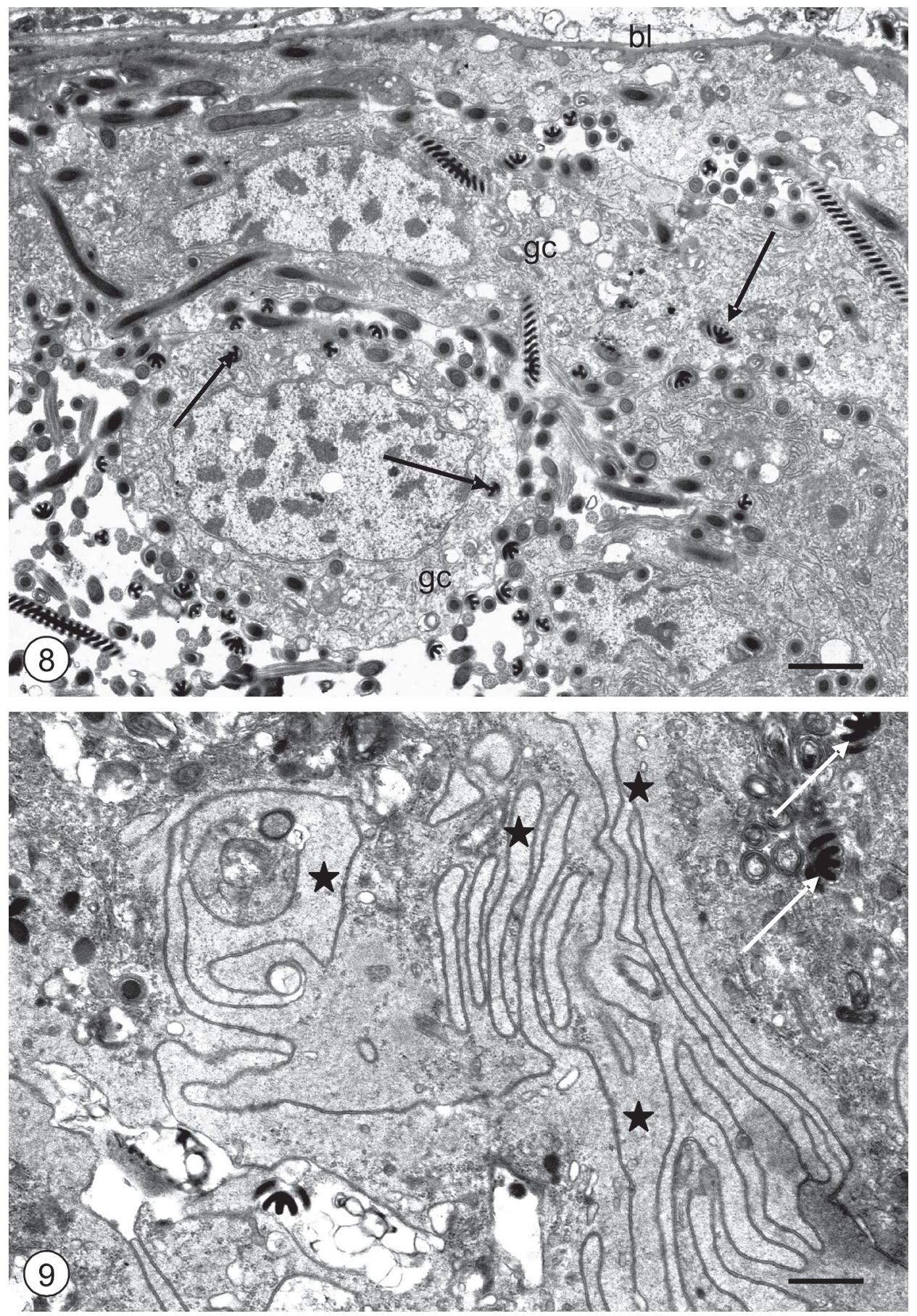


the spermatophore towards the ovaries (ŚWiątek et al., 2007). In detail, the solid structure of the vector tissue observed before copulation is somehow changed (by neurotransmitter(s)?, see Ś WiĄTEK et al., 2007) during copulation, and finally as a result long, finger-like projections of granular and plasmatic cells form folds facing small intercellular spaces which appear between the vector tissue cells (Świątek et al., 2007). As was suggested, the appearance of these spaces enables rapid sperm transfer and facilitates the phagocytosis of defective spermatozoa by granular and plasmatic cells (Ś wiąteK et al., 2007). However, in the previous studies the copulating specimens with spermatozoa just implanted into the copulatory area were not studied. Now, it seems that the vector tissue described as "during sperm transport" (Świątek et al., 2007) was, in fact, the tissue at the final stages of sperm migration. In the present paper we show that in $P$. respirans spermatozoa migrate via the vector tissue in huge accumulations and that the ultrastructure of granular cells does not change during sperm transfer. Granular cells are still tightly packed and intercellular spaces similar to those described in P. geometra and other piscicolid species (Ś WIĄTEK et al., 2007) have never been observed. It seems that the reorganization of the vector tissue cells does not play a key role in sperm transfer as was previously suggested (Ś WIĄteK et al., 2007). Now, we postulate that the sperm is pumped from the spermatophore into the vector tissue at a high pressure, and as a result the vector tissue cells are pushed aside in places where the extracellular matrix fills the gaps between them, and in consequence the spermatozoa can pass quickly through. It seems that the granular cells of the vector tissue change the shape of their cytoplasmic processes after the main mass of sperm passes between them. In our opinion such reorganization: i) allows the retraction of the tissue to the "basal" form, ii) enables the migration of "late" sperm towards the ovaries via small intercellular spaces and finally iii) facilitates the phagocytosis of defective and/or "lost" spermatozoa by the vector tissue cells.

In the previously studied piscicolid leeches two cell types constituting the main mass of vector tissue were described: granular and plasmatic. The only difference found between those kinds of cells was the absence of electron dense granules in plasmatic cells (ŚwiĄTeK et al., 2007). However, although the authors recognize these two cell types they also suggest that the plasmatic and granular cells are the same type of cells in different stages of their synthetic activity (i.e. plasmatic cells have not formed electron-dense granules yet) (ŚWIĄTEK et al., 2007). In P. respirans, all observed profiles of cells constituting the main

Figs. 8-9. Granular cells and spermatozoa

Fig. 8. During sperm transfer some spermatozoa (arrows) are found within the cytoplasm of granular cells $(\mathrm{gc})$. Bl, basal lamina limiting the vector tissue. TEM, bar $=1.4 \mu \mathrm{m}$.

Fig. 9. The cytoplasmic projections of granular cells (stars) do not change their shape during sperm transfer. Arrows mark the spermatozoa within the granular cell cytoplasm. TEM, bar $=0.7 \mu \mathrm{m}$. 
mass of the vector tissue have dense granules, so they all were classified as granular cells. Thus this supports the suggestion that only one kind of cells producing dense granules (of unknown molecular composition) builds the main mass of vector tissue.

\section{TRANSFER PLEMNIKÓW POPRZEZ TKANKE KIERUJACA U PISCICOLA RESPIRANS (CLITELLATA, HIRUDINEA, PISCICOLIDAE)}

\section{STRESZCZENIE}

W kilku grupach pijawek (Acathobdellidae, Glossiphoniidae, Piscicolidae, Erpobdellidae), u których obserwuje się występowanie inseminacji hypodermalnej, plemniki po wypłynięciu ze spermatoforu i przeniknięciu ściany ciała dostają się do jajników. Droga na jakiej zachodzi ten proces jest słabo poznana. U pijawek rybich (Piscicolidae) poniżej wyspecjalizowanej części ciała, do której przyczepiane są spermatofory, czyli pod tzw. polem kopulacyjnym, rozciąga się specyficzny typ tkanki łącznej zwany tkanką kierującą. Jej funkcją jest „kierowanie” plemników wydostających się ze spermatoforu do jajników. W niniejszej pracy po raz pierwszy przedstawiono obrazy transferu plemników poprzez tkankę kierującą u kopulujących osobników, u których spermatofory były wczepione w pole kopulacyjne. Nasze analizy wykazują, iż plemniki migrują poprzez tkankę kierującą w dużych skupieniach, które odpychają od siebie poszczególne fragmenty tkanki kierującej w różnych, przypadkowych miejscach. Powyższe obserwacje są niezgodne z wcześniejszymi poglądami, które zakładały, iż komórki tkanki kierującej w czasie transferu plemników zmieniają znacząco swoje kształty, formując niewielkie, wolne przestrzenie, którymi mogą migrować plemniki. Aktualnie sugerujemy, iż duże ciśnienie, pod jakim plemniki wypływają ze spermatoforu umożliwia im przeniknięcie poprzez tkankę kierującą, a sama zmiana kształtu komórek tkanki kierującej ma drugorzędne znaczenie.

\section{REFERENCES}

Brumpt, E., 1900: Reproduction des Hirudinées. Mem. Soc. Zool. Fr. 13: 286-430.

Fernández, J., Tellez, V., Olea, N., 1992: Hirudinea. In: Harrison F.W., Gardiner S.L. Editors. Microscopic anatomy of invertebrates. Volume 7: Annelida. WileyLiss, Inc., New York: 323-394.

Harant, H., Grassé, P-P., 1959: Classe des Annélides Achetes ou Hirudunés ou Sangsues. In: Grassé P-P. Editor. Traité de Zoologie. Anatomie, Systématique, Biologie. Tome V. Annélides, Myzostomides, Sipunculiens, Echiuriens, Priapuliens, Endoproctes, Phoronidiens. Masson et Cie Éditeurs, Paris: 471-593.

ManN, K.H., 1961: Leeches (Hirudinea), their Structure, Ecology, and Embryology. Pergamon Press, New York.

SAWYer, R.T., 1986: Leech Biology and Behaviour. Clarendon Press, Oxford.

Śmiątek, P., Bielecki, A., Klag, J., 2007: Structure of the vector tissue in piscicolid leeches (Annelida, Hirudinea, Rhynchobdellida, Piscicolidae). J. Morphol. 268: 64-73. 